States has failed to comply with its obligations under international law even though the Bush administration continues to defend its tactics on the grounds of national security.

The release of the Inspector General's report was an important development because it provided the first assessment of the Patriot Act and the Bush Administration's counter-terrorism policies since the "war on terrorism" began. Its timeliness also delayed the enactment of the "Patriot II" legislation, which provides the Attorney General with expanded authority to investigate, arrest and detain individuals suspected of involvement in terrorist activities.

It is important for the Bush administration to remember that it needs the cooperation of its allies and the international community to effectively execute its "war on terrorism." The manner in which it is going about it, however, under the Patriot Act and other policies is not endearing itself to those nations that are genuinely concerned about maintaining universal standards of humanity and protecting human rights under international law. (c)

\section{Dr Klint Alexander}

The author is an international lawyer with the law firm of Wyatt, Tarrant \& Combs, LLP in the United States. This paper was presented as part of the Butterworths International Law Seminar series at the Institute of Advanced Legal Studies, University of London, on June 20, 2003.

\title{
Settlement of disputes under the Financial Services and Markets Act 2000 I
}

\author{
by Dr C Chatterjee, Anna Lefcovitch
}

The dispute procedure under the Financial Services and Markets Act 2000 (the "Act") may be found under Part IX (Hearing and Appeals) and Part XVI (The Ombudsman Scheme). The Act has devised a novel system whereby disputes pertaining to matters under the purview of the Act will be settled either through the Ombudsman Scheme or through Part IX procedure under which Part the Financial Services and Markets Tribunal (the "Tribunal") has been set up. It is the purpose of this two-part article to explain he methods of settling disputes that may arise under the provisions of this Act. Although the Ombudsman Scheme has been detailed in Part XVI and not in Part IX, it is thought appropriate to discuss the Ombudsman Scheme first, and thereafter the Tribunal mechanism.

\section{THE OMBUDSMAN SCHEME}

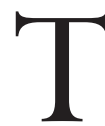

he principal purpose of the Ombudsman Scheme is to provide a mechanism whereby certain disputes may be resolved quickly and with minimum formality by an independent person. It is a compulsory scheme for the resolution of disputes between authorised firms and their customers. This scheme is to be administered by the Scheme operator which must be a body corporate. The Ombudsman Scheme has been detailed in Schedule 17 to the Act. An "Ombudsman" is a person who is a member of the panel, and the panel of Ombudsmen, which is explained below, is detailed in established by the Financial Services Authority (the "FSA"). The Scheme operator must have a chairman, and a board, whose members are a Scheme operator's directors, one of whom must be the chairman. The chairman of the members of the Board must be appointed by the FSA. In the case of the chairman, the approval of the Treasury will be necessary, while on the other hand, paragraph 3 of Schedule 17 provides that the terms of their appointment must be such as to secure their independence from the FSA in the operation of the Scheme.

There must be a panel of ombudsmen which shall enlist persons with appropriate qualifications and experience to 
act as ombudsmen for the purpose of the Scheme. It is for the Scheme operator to determine the terms of appointment of the members of the panel. The Scheme operator must appoint one member of the panel to act as chief ombudsman who shall also be appointed on such terms and for such duration as the Scheme operator considers appropriate. Neither the Act nor the Schedule clarifies the qualifications and experience that may be necessary for becoming a member of the panel; it is believed, however, that persons of sufficient banking experience and proven impartiality will be considered for such positions.

The Scheme operator will not exercise his functions on behalf of the Crown, nor are its board members officers and staff to be regarded as Crown servants. Neither the Chief Ombudsman nor the members of the panel nor the Deputy Ombudsman will have the status of Crown servants. This is so because the impartiality of such members must be ensured.

The Scheme operator remains accountable to the FSA; and the Chief Ombudsman is required to submit its report to the FSA on the discharge of its functions (The frequency with which the Scheme operator is required to submit its report to the FSA is not mentioned in the Schedule and the Act). Each report must distinguish between its functions under its compulsory jurisdiction and its voluntary jurisdiction, which are explained below. The report of the Scheme operator must comply with any requirements specified in the rules, to be made by the FSA. The manner in which the Scheme operator must publish its report is to be determined by itself. The annual budget of the Scheme operator must be approved by the FSA, although it may with the approval of the FSA vary a budget for a financial year at any time after it has been adopted.

The Scheme, including its members, would be liable in damages for anything done or omitted in the discharge or purported discharge of any functions rendered under its compulsory jurisdiction unless the act or omission is shown to have been in bad faith or that it was unlawful or as a result of section 6(1) of the Human Rights Act 1998. Neither the Act nor the Schedule explains the status of the Ombudsman but because of provision for exemption for liability and damages and privilege it is believed that the Ombudsman will be treated like any other ombudsman under various ombudsman schemes or arbitrator under the Arbitration Act 1996.

Paragraph 11 of Schedule 17 provides that:

"For the purposes of the law relating to defamation, proceedings in relation to a complaint which is subject to the compulsory jurisdiction are to be treated as if they were proceedings before a court."

\section{THE SCHEME}

The Scheme means the Ombudsman scheme, and it applies only to a compulsory jurisdiction. The FSA is required to make rules confirming that the complaint must not be entertained unless it has been referred to under the Ombudsman scheme within the time limited prescribed for making such references, although an Ombudsman has an inherent power to extend the time limit for reference in specified circumstances. The FSA may make rules providing that a complaint must not be entertained unless the complainant has previously communicated its substance to the respondent and given him a reasonable opportunity to deal with it. An authorised person who becomes subject to a compulsory jurisdiction as a respondent may be required by the FSA to satisfy such procedures as the FSA may consider appropriate for the resolution of the complaints which may be referred to the Scheme and which arise out of activity which does not come under the activity of the FSA (Part X - Rules and Guidance).

There shall be a Scheme operator who will make rules to be known as "Scheme rules", the purpose of which is, inter alia, to set out the procedure for reference of complaints to the Ombudsman and consideration and referral. The basic objectives of the Scheme rules are as follows:

(a) to specify matters which must be taken into account in determining whether an act or omission was fair and reasonable;

(b) to provide that a complaint made in certain circumstances be dismissed without its merits (this can happen when an Ombudsman may consider that the complaint is frivolous or vexatious, or that the complaint is sub judice because legal proceedings have been brought concerning the subject-matter of the complaint or that the Ombudsman is satisfied that there are other reasons why it would be inappropriate for the scheme to deal with the complainant);

(c) to provide that a complaint in specified circumstances may be referred to another body without the consent of the complainant in order to be determined by this body instead of being determined by an Ombudsman;

(d) to make provisions as to the evidence which may be required and adduced, whether in oral or written form, and the consequences of the parties' failure to produce any information or documents which are required under section 231 (Ombudsman's power to require information);

(e) to allow an Ombudsman to fix time limits for any aspects of the proceedings and to extend a time limit, if necessary;

(f) to make provision for a complaint to be investigated, but not determined by a member of the Scheme operator's staff', instead of by the Ombudsman.

If the Scheme operator proposes to make any scheme rules, it must publish its draft proposals in a way which would bring them to the attention of persons who are likely 
to be affected by them. The draft must be accompanied by a statement whereby representations, by a certain time, will be allowed. The Scheme operator must pay regard to these representations and the consent of the FSA is required before any scheme rules may be made.

Under the Scheme rules a respondent may be required to pay to the Scheme operator such fees as may be specified in the rules, although the rules may provide for the Scheme operator to reduce or waive a fee in a particular case or set different fees for different stages of the proceedings or provide for fees to be refunded in specified circumstances or make different provisions for different kinds of complaint.

\section{In addition:}

(1) Scheme rules may require a respondent to pay to the Scheme operator such fees as may be specified in the rules.

(2) The rules may, among other things -

(a) provide for the Scheme operator to reduce or waive a fee in a particular case;

(b) set different fees for different stages of the proceedings on a complaint;

(c) provide for fees to be refunded in specified circumstances;

(d) make different provision for different kinds of complaint (paragraph 15 of Sched 17 of the FSMA).”

\section{JURISDICTION}

The Ombudsman Scheme shall operate under two jurisdictions: compulsory and voluntary. The compulsory jurisdiction rules apply when a complaint is related to an act or omission of a person (the respondent) in carrying on an activity.

\section{The voluntary jurisdiction}

The voluntary jurisdiction is different from the compulsory jurisdiction under the Ombudsman Scheme. Part IV of Schedule $17 \mathrm{n}$ to the Act deals with the voluntary jurisdiction. The rules in regard to this jurisdiction are to be developed by the Scheme Operator and be approved by the FSA. The eligibility of complainants and complaints will be determined by referring to such rules and forms of reference in as may be developed by the Scheme Operator and approved by the FSA. Different standard terms may be fixed with respect to different matters or cases. These standard terms may, in particular, require payments by participants to the Scheme operator; the latter shall determine the amounts and time(s) of payment.

The standard terms may also make provisions for award of costs on the determination of the complaint. The standard terms may not be varied or altered by the Scheme operator without the approval of the FSA. Immunity for liability is allowed in respect of the persons who may be directly involved under voluntary jurisdiction. Paragraph 18(5) of Schedule 13 provides that standard terms may provide that none of the following is to be liable in damage for anything done or omitted in the discharge or purported discharge of functions in connection with this jurisdiction:

(a) the Scheme operator;

(b) any member of the governing body;

(c) any member of the staff; and

(d) any person acting as an ombudsman for the purposes of the Scheme.

In appropriate circumstances the Scheme operator may delegate any power of the voluntary jurisdiction of the Ombudsman scheme to a relevant body with the approval of the FSA. It is believed that delegation will be allowed when expertise of specific bodies is be found necessary. In the context of delegation of power a "relevant body" is one which is responsible for the resolution of disputes, and that which is capable of exercising the jurisdiction in a way which is compatible with the requirements under this Act, and with particular reference to the nature of the complaint.

\section{Compulsory jurisdiction}

The following conditions are to be satisfied in order to refer a dispute to the compulsory jurisdiction under the Scheme:

(a) that the complainant is eligible and wishes to have the complaint dealt with under the Scheme;

(b) that at the time of the act or omission which gave rise to the complaint, the respondent was an authorised person; and

(c) that the act or omission to which the complaint relates occurred at a time when compulsory jurisdiction rules in relation to the activity in question were in force (section 226 of the FSMA).

"Compulsory jurisdiction rules" stand for those rules which have been or may be made by the FSA for the purposes of section 226 (Compulsory jurisdiction); activities may be described under various specified categories. In order to be eligible for referring a dispute to the compulsory jurisdiction a person is required to come under a class of person to be specified in the rules, and persons other than individuals may be included in the rules. The Scheme will work only in the circumstances specified in the rules.

Section 228 is concerned with the determination of complaints under the compulsory jurisdiction. The determination of a complaint will be made by the Ombudsman on the basis of whether he believes it to be fair and reasonable in all the circumstances of a case. It is 
believed that an objective test will be adopted by the Ombudsman in determining what is fair and reasonable in all the circumstances of a case. After determining a complaint, the Ombudsman must submit a duly signed written statement of his determination to the complainant and the respondent giving reasons thereof. The complainant will be required to notify the Ombudsman, in writing, by a specified date, whether he accepts or rejects the determination; and in the event of the complainant's accepting the determination it becomes binding on both parties, the complainant and the respondent, and the determination must be regarded as final.

If the complainant fails to notify the Ombudsman of his acceptance or rejection of the determination by the stipulated dated, it will be assumed that he has rejected it. The Ombudsman then shall notify the respondent of the outcome. Therefore, it is for the complainant to accept or reject a determination; the fact remains that if a determination is made against the complainant or that the complaint is regarded to be unfounded, then naturally, the complainant will reject it, and the question may arise, what remedies does the respondent receive particularly when the complaint was regarded as derogatory against the respondent. A determination duly signed and certified by the Ombudsman is to be treated as evidence to the effect that the determination was made under the Scheme.

A determination may be made for:

(a) a "money award"; and the amount will represent what may be considered by the Ombudsman to be fair compensation for loss or damage suffered by the complainant. Obviously, the onus of establishing the extent of the loss or damage suffered is on the complainant; or

(b) a direction may be issued requiring the respondent to take such steps in relation to the complaint as the Ombudsman may consider just and appropriate. Compliance with a direction is enforceable by an injunction or in Scotland, enforceable by an order under section 45 of the Court of Session Act 1988.

The primary objective of a money award is to compensate for financial loss or damage of a specific kind (s 229(3) of the FSMA). The term "any other loss" is rather broad; however a loss may not be taken into account unless it is quantifiable. What may be regarded as the minimum amount as fair compensation for a particular kind of loss or damage may be specified by the FSA. A money award may not exceed the monetary limit, that is, the claim; however if, in the considered view of the Ombudsman a fair compensation would require a larger amount, then the Ombudsman may recommend only that the respondent be allowed to pay the complainant the balance. A money award may also bear interest at a rate and as from a date specified, in the award, and is enforceable in accordance with Part III of Schedule 17. It is expected that interest compensation would be charged along the lines adopted by county courts or the High Court. A money award is to be treated as a county court order and enforced accordingly (In Northern Ireland it is to be enforced as a money judgement under the Judgement Enforcement (Northern Ireland) Order 1981, and in Scotland it is to be enforced by the sheriff as if it were a judgment or order of the sheriff).

\section{PROCEDURE}

The Scheme operator is required to give any rules that it may make to the FSA as it must give written notice to the FSA when it may revoke any voluntary jurisdiction of the rules. All rules must be in written form and they must be made available to the public. These rules may be verified by means of a certificate signed by an authorised member of the Scheme operator staff, and it should be treated as evidence, or sufficient evidence in Scotland. The certificate must confirm that the rules are made by the Scheme operator and that a copy is the true copy of the rules.

Where the Scheme operator may propose to make voluntary jurisdiction rules, it must publish its draft version for the purpose of bringing it to the attention of the public, and the draft must be accompanied by an explanation of the proposed rules and a statement that representations to the proposals may be made to the Scheme operator within a specified period of time. The Scheme operator must pay attention to any representations made to it, and if the differences between the Scheme Operator's draft and the public opinion are significant, then the Scheme Operator must publish a statement of the difference.

\section{OMBUDSMAN'S POWER TO REQUIRE INFORMATION}

Under section 231 of the Act an ombudsman may by notice in writing require a party to a complaint to provide specified information or information of specified description or to produce specified documents or documents of a specified description by the time specified, or in the absence of any specified time then within a reasonable period and in such manner and form as may be specified. The question of which documents or information is necessary will be determined by the Ombudsman himself/herself, and an ombudsman has the authority to take copies or extracts from any document or require a person producing a document to provide an explanation of a document.

If a document is not produced by the party who has required a notice on the ground that he cannot produce it, then the Ombudsman may require him to state to the best of his knowledge and belief where the document is. If a person claims a lien on a document, its production does not affect the lien. If a person fails to comply with the requirements of section 231, the Ombudsman may request the court to inquire into the case, and if the court is 
satisfied that the party concerned failed without reasonable excuse to comply with the requirement, then his failure may be regarded as a contempt of court. Contempt of court in the context of section 232 would mean the High Court in England and Wales, and the Court of Session in Scotland. In regard to the data protection, section 233 provides that:

$$
\begin{aligned}
& \text { "In section } 31 \text { of the Data Protection Act } 1998 \text { (regulatory } \\
& \text { activity), after subsection (4), insert - } \\
& \text { "(4A) Personal data processed for the purpose of discharging } \\
& \text { any function which is conferred by or under Part XVI of the } \\
& \text { Financial Services and Markets Act } 2000 \text { on the body } \\
& \text { established by the Financial Services Authority for the purposes } \\
& \text { of that Part are exempt from the subject information provisions } \\
& \text { in any case to the extent to which the application of those } \\
& \text { provisions to the data would be likely to prejudice the proper } \\
& \text { discharge of the function." }
\end{aligned}
$$

The FSA may authorise the persons or any class of authorised person to meet the expenses of the Ombudsman Scheme, particularly as to the establishment of the scheme and the operation of the compulsory jurisdiction.

It is believed that the purpose of the voluntary jurisdiction is to provide authorised persons an opportunity to have a confirmation whether the authorised person is already in breach of the relevant provision of the Act, and therefore all expenses in completing these formalities must be borne by the person who decides to refer the matter to the voluntary jurisdiction of the Ombudsman scheme.

The other institution involved in settling disputes in regard to issues arising under the Act is to be the Financial Services and Markets Tribunal (the "Tribunal"). The Lord Chancellor has the authority to make rules as may appear to be expedient in respect of the conduct of the procedures before the Tribunal. Schedule 13 to the Act deals with the constitution and procedure of the Tribunal. There shall be a panel of persons for the purposes of serving as Chairman of the Tribunal, and membership of the panel of Chairmen is open to persons who have seven years general qualification within the meaning of section 71 of the Court and Legal Services Act 1990; alternatively he/she must be an advocate or solicitor in Scotland, or a member of the Bar of Northern Ireland, or a solicitor of the Supreme Court of Northern Ireland of at least seven years standing. At least one member of the Panel must be taken from the Scottish jurisdiction.

In addition to such persons, the Lord Chancellor "shall also appoint a panel of persons who appear to him to be qualified by experience or otherwise to deal with the matters of the kind that may be referred to the Tribunal" (sub-para 4 of Sched 15). This provision gives the Lord Chancellor a very wide discretion in respect of lay panel members as to the appointment of a panel member. One of the members of the panel of Chairmen must be appointed to preside over the functions of the Tribunal, and he/she shall be known as the President of the Financial Services and Markets Tribunal.

Section 71 of the Court and Legal Services Act 1990 provides that:

"(2) Schedule 10 shall have effect for the purpose of making amendments to other enactments, measures and statutory instruments which relate to qualification for judicial and certain other appointments.

(3) For the purposes of this section, a person has -

(a) a "Supreme Court qualification" if he has a right of audience in relation to all proceedings in the Supreme Court;

(b) a "High Court qualification" if he has a right of audience in relation to all proceedings in the High Court;

(c) a "general qualification" if he has a right of audience in relation to any class of proceedings in any part of the Supreme Court, or all proceedings in county courts or magistrates' courts;

(d) a "Crown Court qualification" if he has a right of audience in relation to all proceedings in the Crown Court;

(e) a "county court qualification if he has a right of audience in relation to all proceedings in county courts;

(f) a "magistrates" court qualification" if he has a right of audience in relation to all proceedings in magistrates' courts.

(4) References in subsection (3) to a right of audience are references to a right of audience granted by an authorised body.

(5) Any reference in any enactment, measure or statutory instrument to a person having such a qualification of a particular number of years' length shall be construed as a reference to a person who-

(a) for the time being has that qualification, and

(b) has had it for a period (which need not be continuous) of at least that number of years.

[(6) Any period for which a person has a right of audience but was, as a result of disciplinary proceedings, prevented by the authorised body concerned from exercising it shall not count towards the period mentioned in subsection (5)(b).]"

There may be a deputy-president who shall have such functions in relation to the Tribunal as the President may assign to him. No person may be appointed as the President or Deputy-President of the Tribunal unless he/she has 10 years general qualification within the 
meaning of section 71 of the Courts and Legal Services Act 1990 (or an equivalent period as an advocate or solicitor in Scotland, member of the Bar of Northern Ireland, or a solicitor of the Supreme Court of Northern Ireland). If the President is absent, the Deputy-President will take over the functions of the President, and in the absence of the Deputy-President the Lord Chancellor will appoint another person from the Panel for that purpose. The actual terms of office have not been determined, but each member of the Panel of Chairmen and the lay panel is to hold and vacate the office in accordance with the terms of appointment. The Lord Chancellor may remove any member of the Panel on the grounds of incapacity or misbehaviour. A panel member is eligible for appointment but, of course, he has a right to resign office by giving the Lord Chancellor a written notice.

The members of the panel will be paid such remuneration and allowances as the Lord Chancellor may determine. The Tribunal will also be assisted by other staff and all expenses in the serving of the Tribunal will be met by the Lord Chancellor's Department.

\section{CONSTITUTION OF THE TRIBUNAL}

When a case may be referred to the Tribunal, members of it will be chosen from a panel of Chairmen or the lay panel in accordance with the arrangements that may be made by the President. Such arrangements will be known as "standing arrangements", would also provide for at least one member to be selected from the panel of chairmen. If a person serving as a member of the Tribunal pertaining to the reference becomes unable to act, then other members will be invited to deal with it, and where it is being dealt with by a single member and he is unable to act, then another member of the panel of chairmen may be selected in accordance with the standing arrangements. If a matter involves a question of fact of a particular difficulty, the Tribunal may appoint an expert or more to provide assistance.

\section{TRIBUNAL PROCEDURE}

The Tribunal must sit at such place or places and at such times as the Lord Chancellor may direct.The Lord Chancellor is required to make rules in regard to the following:

(a) the manner in which references are to be made to the Tribunal;

(b) holding of hearings in private;

(c) eligibility of persons who may appears on behalf of the parties;

(d) the kind of member of the Panel of chairmen who shall hear and determine interlocutory matters;

(e) procedures as to suspension of decisions of the FSA;

(f) procedures as to withdrawal of references; and (g) formalities as to the registration, publication and proof of decisions and orders.

According to section 133 of the Act the reference to the Tribunal must be made within a period of 28 days beginning with the date on which a decision notice or supervisory notice is given or such other period as may be specified in the Rules made under section 132 of the Act.

The Tribunal has the inherent power to allow a reference to be made after 28 days; it is not clear, however, on what basis the Tribunal would exercise discretionary power in this regard. After a reference has been made to the Tribunal, the latter must determine what should be the appropriate action for the Financial Services Authority to take in relation to that matter and upon determination the Tribunal must remit the matter to the FSA with such directions, if any, as it may consider appropriate for giving effect to its determination. However, in determining a reference made as a result of the decision matters, the Tribunal may not direct the FSA to take action. Furthermore, in determining a reference made as a result of a supervisory notice (s 395) the Tribunal may not direct the FSA to take action which would have otherwise required the giving of a decision notice.

\section{"In determining a reference made as a result of a supervisory notice, the Tribunal may not direct the Authority to take action which would have otherwise required the giving of a decision notice" (s 133(7)).}

However, the Tribunal may, in determining the reference, make recommendations as to the regulatory provisions. The FSA cannot take action specifying a decision notice until the period for the making appeal on that decision is over, or if a matter is referred to the Tribunal, and an appeal is made against the Tribunal's determination then until the matter has been finally disposed of.

\section{EVIDENCE}

The Tribunal may consider any evidence relating to subject-matter in relation to which a reference has been made irrespective of whether it was available to the FSA at the material time. The procedure of giving evidence has been detailed in Schedule 13 to the Act. The Tribunal may by summons require any person to attend at such place and time as may be specified in the summons, in order to give evidence or to produce any document in his custody or control if the Tribunal finds it necessary to examine that evidence or documents. It may take evidence on oath or may instead of administering an oath require the person concerned to make and subscribe a declaration of the truth of the matter in respect of which he has examined. A person who without a reasonable excuse refuses or fails to attend the Tribunal following the issue of the summons to give evidence or alters, suppresses, conceals or destroys or refuses to produce a document which he may be required to produce for the purposes of proceedings is guilty of an 
offence. In this regard the Tribunal has power comparable to the court of law.

A decision of the Tribunal may be taken by majority. All decisions must state its voting structure and must be accompanied by reasons. Each party to a reference must be informed of its decision and the Treasury must also be provided with a copy of its decision.

If in the opinion of the Tribunal, a party has acted vexatiously, frivolously or unreasonably the Tribunal may order that party to pay the other party the full or part of the costs or expenses of the proceedings. If, on the other hand, the Tribunal considers that a decision of the FSA which has been referred to the Tribunal was unreasonable, it may order the FSA to pay another party to the proceedings full or part of the costs and expenses incurred by the other party in connection with the proceedings.

\section{LEGAL ASSISTANCE BEFORE THE TRIBUNAL}

The Lord Chancellor may establish a scheme regulating the provision of legal assistance in connection with proceedings before the Tribunal. The criteria for eligibility for assistance must be established under the legal assistance scheme, and the procedure for making applications for legal assistance; appeals for the refusal of applications, revocations or variations of procedures and restrictions thereof must be prescribed by the legal assistance scheme.
The funding of the legal assistance scheme must be provided by the FSA to the Lord Chancellor.

An order of the Tribunal may be enforced as if it were an order of the county court in England and Wales or order of the Court of Session in Scotland. Appeals from the findings of the Tribunal may with permission of the Tribunal be lodged to the Court of Appeal on a point of law, in Scotland the Court of Session. If on an appeal the court considers that the decision/finding of the Tribunal was wrong in law, it may remit the matter to the Tribunal for re-hearing and determination by it or the Court of Appeal or the Court of Session as the case may be, and may itself make a determination and appeal may not be brought from a decision of the Court of Appeal without the leave of the Court of Appeal or the House of Lords. The Lord Chancellor may under section 132 make provisions for regulating or prescribing "any matters incidental to or consequential on an appeal under that section."

\section{Chatterjee}

LLM (Cambridge), LLM, PhD (London), barrister, Law Department, London Guildhall University

Anna Lefcovitch

LLM, solicitor, E C Harris

\section{SALS Lectures}

\section{CLIFFORD CHANCE TO SPONSOR LECTURES}

Clifford Chance have kindly agreed to sponsor forthcoming lectures on financial regulation, EU law and banking law. Dates and further details will be announced as soon as possible.

Wednesday, 19 November, 5.30-7.00

\section{THE HON MR JUSTICE TOULSON}

Chairman, Law Commission

Partial defences to murder

Monday 24 November

\section{MICHAEL TUGENDHAT QC}

5 Raymond Buildings

Privacy and celebrity

(this updates the speaker's highly successful SALS lecture on the same subject given in May 2001)
Thursday, 27 November

\section{LISA WEBLEY AND LIZ DUFF}

University of Westminster

Women solicitors in the 21 st century: true equality?

Thursday, 4 December

\section{BEN BRANDON}

Partner, Russell Jones \& Walker

30 years of anti-terrorist legislation

Friday, 16 January, 4pm

Gosforth Park Hotel, Newcastle

(speaker to be confirmed); chair ASHLEY WILTON, head, Newcastle Law School

Recovery of general damages where liquidated damages fail

(In Newcastle in association with Watson Burton, solicitors) 